\title{
Pengembangan Rencana Pelaksanaan Pembelajaran (RPP) Berbasis Pendekatan Saintifik Bagi Guru Pembimbing PPG UM Purwokerto
}

\author{
Pudiyono, Miftahul Furqon \\ Universitas Muhammadiyah Purwokerto \\ Email: pudiyono@ump.ac.id
}

\begin{abstract}
Abstrak
Pengabdian kepada masyarakat ini merupakan solusi sebagai tindak lanjut dari kegiatan Pendidikan Profesi Guru (PPG) yang dilakukan oleh FKIP UM Purwokerto sejak tahun 2018. Keterlibatan guru merupakan keharusan dalam pelaksanaan PPG. Namun, belum semua guru memiliki kemampuan yang baik terhadap pelaksanaan pembelajaran berbasis saintifik sebagaimana diamanahkan Standar Pendidikan Guru, yaitu PP 55/SPG/2017. Dengan kondisi ini, wajib bagi LPTK penyelenggara PPG untuk menjamin standar kemampuan dosen dan guru pembimbing untuk memiliki keterampilan yang distandarkan. Metode Ipteks bagi Masyarakat (IbM) ini dilakukan melalui praktik workshop pembuatan RPP berbasis saintifik kepada guru pembimbing PPG secara daring. Produk kerja pengabdian ini adalah RPP sebagai cermin pemahaman langkah pembelajaran yang akan dipraktikkan dalam PBM di kelas. Peserta pelatihan ini merupakan 13 guru bahasa Inggris SMP, SMK, dan SMA. Program ini juga bekerjasama dengan MGMP Bahasa Inggris di Kabupaten Banyumas. Pengabdian ini diharapkan menjadi strategi penting untuk melaksanakan pembelajaran yang mendorong siswa menjadi kreatif dan berfikir ilmiah. Bekal ini diharapkan dapat menjadi modal kepercayaan diri para guru untuk mengembangkan kemampuan profesional dan menerapkan kinerja saintifik dengan langkah yang benar dalam pembelajaran untuk pengembangan kegiatan profesional mereka.
\end{abstract}

Kata kunci: RPP, pendekatan saintifik, guru pembimbing PPG UM Purwokerto

\section{Abstract}

This community service proposes a solution and follow-up of Pendidikan Profesi Guru (PPG) which has been held by FKIP Universitas Muhammadiyah Purwokerto since 2018. Teacher's involvment is a crucial part in PPG. However, some of the teaching practices have not shown the scientific-based method as regulated in Standar Pendidikan Guru, PP 55/SPG/2017. Viewing this condition, LPTK holding the PPG program must guarantee the standard of lecturers or teachers' competencies supervising the PPG participants. This community service held a workshop of developing scientific-based lesson plan (RPP) through online presentation and discussion. The product of this program was used as a reflection of understanding the teaching and learning process that is later applied in the class. The participants of this program were 13 Junior and Senior High School teachers. This program also involved the MGMP Bahasa Inggris Banyumas. This community service is expected to become a crucial strategy to support the teaching practices that lead students to be a creative and critical thinker. Moreover, teachers are also expected to be more professional by conducting standardized scientific-based teaching method after joining this program.

Keywords: lesson plan, scientific-based approach, teacher-supervisors of PPG UM Purwokerto

\section{PENDAHULUAN}

FKIP UM Purwokerto sudah melaksanakan PPG sejak tahun 2018. Pelaksanaan Pendidikan Profesi Guru (PPG) melibatkan banyak dosen dan guru, terutama dalam praktik pelaksanaan PPL di sekolah dan ujian kinerja atau ujian akhir Praktik Pengalaman Lapangan (PPL). Untuk pelaksanaan tugas negara ini, perlu dilakukan upaya untuk membangun mutu standar kinerja baik untuk dosen mupun untuk guru pembimbing, sehingga hasil akhir dari program PPG akan mencapai derajat kompetensi yang memenuhi standar ketentuan pemerintah. Peraturan pemerintah Nomor 55 tahun 2017 tentang Standar Pendidikan guru menyebutkan bahwa dalam pelaksanaan pembelajaran, guru harus mampu melaksanakan 
pembelajaran dengan kriteria sebagai berikut: interaktif, holistik, integratif, saintifik, kontekstual, tematik, efektif, kolaboratif, inovatif, dan berpusat pada siswa.

Untuk menerapkan pembelajaran dengan karakteristik tersebut di atas, LPTK harus memulai dari pelaksanaan PPG terlebih dahulu. PPG merupakan lembaga resmi untuk menghasilkan guru-guru yang profesional. Oleh karenanya, guru profesional harus mampu melaksanakan pembelajaran dengan karakteristik sebagaimana ditetntukan oleh pemerintah. Namun demikian, upaya untuk mampu mengembangkan kecakapan itu tidak hanya tanggung jawab PPG semata. Pengembangan kompetensi tersebut harus dilakukan secara integratif pada semua unit dan kesempatan yang memungkinkan. Oleh karanaya, program Ipteks bagi Masyarakat (IbM) sebagai pengabdian kepada masyarakat sangat tepat untuk ikut berperan pengembangan hal itu.

Teknik mengembangkan mutu pembelajaran dimulai melalui tindakan pemahaman pembelajaran saintifik yang prima bagi guru. Oleh karenanya, usaha untuk sosialisasi harus banyak dilakukan dilakukan dalam upaya memperoleh hasil yang terbaik. Hal ini pulalah yang mendasari usulan untuk melakukan kegiatan dengan mengembangkan keterampilan mendesain RPP sebagai langkah awal. Langkah ilmiah pembelajaran ini mempunyai tingkat pemahaman yang sangat beragam, sebagaimana beragamnya bidang ilmu. Bahasa Inggris dan bahasa yang lain juga mempunyai kekhususan dalam melakkukan pendekatan ilmiah dalam pembelajaran. Oleh karenanya, bentuk pelatihan untuk membangun pemahaman yang sama sangat diperlukan. Pada dasarnya, kegiatan ini dilakukan untuk kemajuan tidak hanya bagi lembaga sekolah, tetapi juga bagi kemampuan profesional individu guru yang terkait.

Berkenaan dengan fungsi FKIP UM Purwokerto sebagai Pengelola dan menjadi stake holder Sekolah Laboratorium, Fakultas perlu mengambil peran untuk berpartisipasi ikut melaksanakan pengembangan mutu dan mendukung program kinerja sekolah. Dengan memperhatikan bahwa program ini mampu menuntun para guru untuk bekerja lebih profesional tidak hanya mendasarkan pada kemampuan individu saja melainkan dengan pembelajaran dari LPTK sebagai lembaga yang bisa dipercaya kredibilitasnya dalam bidang pendidikan, IbM ini akan memberikan manfaat yang sangat signifikan terhadap sekolah, lembaga terkait, dan juga dunia pendidikan di Indonesia. Untuk itu, pelatihan pengembangan SDM guru perlu segera diprogram, direalisasi agar para guru akan senantiasa mampu dan terampil memperbaiki kualitas diri dalam mengemas, mempraktikkan, dan mengevaluasi pembelajaran untuk tujuan membelajarkan siswa secara analitis, kreatif, interaktif dan inovatif.

\section{BAHAN DAN METODE}

Pengabdian ini menerapkan metode pelatihan mendesain RPP (utamanya pada langkah inti pembelajarannya). Secara teknis, pengabdian ini dilaksanakan sebagai berikut. Kegiatan diawali dengan presentasi knowledge building dan pola berfikir saintifik, yaitu presentasi untuk membangun pemahaman konsep berfikir saintifik pada pembelajaran bahasa Inggris untuk semua level sekolah. Kegiatan ini dikembangkan dengan melakukan presentasi dan diskusi juga, sehingga keterlibatan peserta terjaga. Materi presentasi juga terkait dengan langkah-langkah berfikir saintifik yang paling sesuai diterapkan, sehingga memudahkan peserta untuk mampu memahami dengan baik. Selanjutnya, peserta diberi Kompetensi Dasar (KD) dari Kurikulum 2013 yang berbeda tiap kelompok dan diminta untuk mendesain langkah pembelajaran bahasa Inggris berbasis pendekatan saintifik. Pada tahap ini, instruktur melakukan monitoring terhadap kinerja peserta, membantu bila ditemukan persoalan, sehingga hasilnya diharapkan benar. Kemudian, diskusi dan pemberian timbal balik dilaksanakan untuk mendapatkan pandangan yang komprehensif terhadap model pembelajaran bahasa Inggris berbasis saintifik untuk tiap skil bahasa. Setelah itu, dilakukan tahap perbaikan dan pengumpulan kembali RPP. Program ini diakhiri dengan kegiatan selanjutnya, yaitu refleksi hasil pelatihan sebagai pengetahuan nyata untuk investasi tugas profesional kedepan. 


\section{HASIL}

Mitra di sini adalah guru pembimbing dan penguji program PPG, khususnya para guru dalam kegiatan PPL. Pelaksanaan PPL PPG melibatkan banyak guru bidang studi Bahasa Inggris dengan tingkat kemampuan akademik dan kompetensi profesioanal yang beragam. Oleh karena itu, di dalam pelaksanaan PPL PPG dimungkinkan akan terjadi rentang kemampuan yang panjang dan beragam, sehingga tujuan penyelenggaraan PPG untuk menghasilkan kemampuan profesional guru bisa terancam.

Kondisi rentang kemampuan beragam terhadap kemampuan pembelajaran berbasis saintifik para guru terkait erat dengan pemahaman sikap ilmiah yang masih jauh dengan lingkungan kerja profesionalnya. Guru tidak pernah melakukan kegiatan penelitian, sehingga konsep ilmiah masih belum jelas dimaknai. Hal itu tentu sangat berimbas pada pola pembelajaran yang dilakukan kesehariannya. Program IbM ini mendukung guru untuk mahir melakukan model pembelajaran berorientasi pada student centered, yaitu memanusiakan siswa. Tidak dilakukan dengan penjelasan verbalisme semata. Melalui metode pelatihan pembuatan RPP ini, peserta mampu membuat RPP berbasis pendekatan saintifik yang merujuk kepada peningkatan kreatifitas dan produktifitas siswa secara ilmiah dan sesuai dengan pengembangan kompetensi pembelajaran Standar Pendidikan Guru pada PP Nomor 55 tahun 2017.

\section{PEMBAHASAN}

Kegiatan pengabdian kepada masyarakat ini secara garis besar menghasilkan desain RPP berbasis saintifik oleh para guru pendamping PPG UM Purwokerto yang lebih mengarah terhadap knowledge building atau konstruksi pengetahuan awal siswa. Berikut adalah pembahasan menurut langkah yang dilaksanakan dalam kegiatan ini.

Kegiatan awal berupa presentasi dan diskusi dengen peserta pelatihan dilakukan secara daring. Presentasi berupa video berdurasi kurang lebih 15 menit memaparkan bentuk RPP berbasis saintifik dipelajari oleh peserta pelatihan di awal kegiatan. Kemudian, diskusi secara daring dilakukan sebagai tindak lanjut dari apa yang dimuat dalam video presentasi tersebut. Proses diskusi merupakan bentuk konfirmasi dari kegiatan perancangan dan pelaksanaan pembelajaran yang sudah dilaksanakan oleh peserta pelatihan di sekolah. Dengan adanya diskusi tersebut, perbaikan RPP dan pelaksanaan pembelajaran dapat direalisasikan.

Kegiatan pengabdian kepada masyarakat ini diakhiri dengan tahap konklusi, yaitu refleksi secara detail atas pelaksanaan pembelajaran oleh peserta di sekolah sebagai investasi tugas profesional di masa yang akan datang.

\section{KESIMPULAN DAN SARAN}

Pengabdian kepada masyarakat berupa kegiatan pelatihan pengembangan RPP berbasis saintifik ini memberikan tolok ukur terhadap proses pembelajaran yang bertujuan untuk mengaktifkan pengetahuan awal siswa. Berdasarkan kegiatan yang dilaksanakan, dapat disimpulkan bahwa peserta pelatihan mampu mengembangkan dan merefleksikan RPP berbasis saintifik. Solusi terhadap persoalan kompetensi profesi guru pembimbing terkait perbedaan pemahaman penerapan pembelajaran berbasis saintifik dapat diperoleh dari kegiatan ini.

\section{DAFTAR PUSTAKA}

Lindolof, Thomas R. (-). Qualitative communication research methods. Thousand Oaks: Saga Publications.

Marwoto, dkk. (1987). Komposisi praktis. Yogyakarta: P.T. Hanindita. 
Nababan. (1991). Foreign language learning Indonesia. TEFLIN, 2 (-), Universitas Sanata Darma, Yogyakarta.

Nunan, David. (1991). Language teaaching methodology: A textbook for teacher. UK Prentice Hall International Ltd.

Rubin, Herbert. (1995). Qualitative interviewin: The art of hearing data. London: Saga Publication.

Surakhmad. W. (1969). Guru dan pendidikannya. Ditjen Pendidikan Guru dan Tenaga Teknis $\mathrm{P}$ dan $\mathrm{K}$, Jakarta. 